\title{
Europejski Zielony Ład wyzwaniem dla transformacji polskiego przemysłu naftowego i gazowniczego
}

\section{European Green Deal - a challenge for the transformation of the Polish oil and gas industry}

\author{
Maria Ciechanowska \\ Instytut Nafty i Gazu - Państwowy Instytut Badawczy
}

\begin{abstract}
STRESZCZENIE: W artykule przedstawiono założenia strategicznego programu ustanowionego przez Komisję Europejską pn. Europejski Zielony Ład, którego celem jest uczynienie Europy kontynentem neutralnym dla klimatu do roku 2050. Omówiono najważniejsze inicjatywy tego programu, m.in. osiągnięcie neutralności emisyjnej na poziomie globalnym dla $\mathrm{CO}_{2}$, włączenie w szerokim zakresie odnawialnych źródeł energii do systemu energetycznego, zapewnienie gospodarki o obiegu zamkniętym czy uzyskanie zerowego poziomu emisji zanieczyszczeń na rzecz nietoksycznego środowiska. Zaprezentowano cele transformacji przemysłowej, w której główną rolę odgrywa energetyka skupiająca się na dekarbonizacji i dążąca do zastąpienia paliw kopalnych (gazu ziemnego, ropy naftowej, węgla) nowymi nośnikami (wodór), minimalizującymi degradację środowiska naturalnego. Wskazano na różne dookreślenia wodoru przyjmowane w praktyce (wodór zielony, niebieski, fioletowy, czarny), w zależności od źródła jego pochodzenia. Pełną akceptację UE ma tzw. wodór zielony, wytwarzany z wykorzystaniem energii odnawialnej (m.in. z elektrowni fotowoltaicznych czy morskich farm wiatrowych). W procesie generowania pozostawia on najmniejszy ślad węglowy. Zwrócono uwagę na strategie wodorowe opracowywane w poszczególnych krajach członkowskich UE, w tym i w Polsce, które uwzględniają nie tylko nowe technologie pozyskiwania wodoru, ale też cały kompleks zagadnień związanych z jego przesyłem, dystrybucją, magazynowaniem i użytkowaniem. Omówiono tzw. programy wodorowe, realizowane w kraju przez różne spółki Skarbu Państwa, jak i INiG - PIB, dotyczące m.in. stacji badawczej tankowania pojazdów wodorem, instalacji doczyszczania wodoru czy utworzenia laboratorium do badań paliw alternatywnych. Przedstawiono programy wspomagające transformację gospodarki w obszarze badań, rozwoju i innowacji, takie m.in. jak programy ramowe Horyzont Europa czy Cyfrowa Europa, stanowiące źródło finansowania tych przemian.
\end{abstract}

Słowa kluczowe: Europejski Zielony Ład, transformacja sektora energetyki, wodór jako nośnik energii.

ABSTRACT: The article presents the assumptions of the strategic programme established by the European Commission called the European Green Deal. Its goal is to make Europe a climate neutral continent by 2050. The most important initiatives of this programme were discussed, such as achieving emission neutrality on a global level for $\mathrm{CO}_{2}$, including a wide range of renewable energy sources in the energy system, establishing a circular economy or achieving zero emissions of pollutants for a non-toxic environment. The objectives of the industrial transformation are presented, in which the main role is played by the energy sector focusing on decarbonisation and replacing fossil fuels (natural gas, oil, coal) with new carriers (hydrogen), reducing environmental degradation. Various labels of hydrogen (green, blue, violet, black) used in practice, depending on the source, are indicated. The so-called green hydrogen produced with the use of renewable energy (e.g. from photovoltaic power plants or offshore wind farms) enjoys full acceptance by the EU. It leaves the smallest carbon footprint in the process of generation. Attention was drawn to the hydrogen strategies developed in individual EU Member States, including Poland, which take into account not only new technologies of obtaining hydrogen, but also the entire complex of issues related to its transmission, distribution, storage and use. The discussion focused on the so-called hydrogen programs carried out in Poland by various State Treasury companies, as well as the Oil and Gas Institute - National Research Institute, concerning, among other things, a research station for the refuelling of vehicles with hydrogen, a hydrogen purification system or the creation of a laboratory for testing alternative fuels. Programmes supporting the transformation of the economy in the area of research, development and innovation, such as the Horizon Europe or Digital Europe framework programmes, are presented as a source of financing for these transformation efforts.

Key words: European Green Deal, energy sector transformation, hydrogen as an energy carrier. 


\section{Europejski Zielony Ład}

Europejski Zielony Ład (EZL) to nazwa ambitnego strategicznego programu UE, którego głównym celem, ale nie jedynym, jest uczynienie Europy pierwszym kontynentem neutralnym dla klimatu do roku 2050 (Komisja Europejska, 2019).

Cel ten planuje się osiągnąc m.in. poprzez:

- bardziej efektywne wykorzystanie zasobów - dzięki przejściu na czystą gospodarkę o obiegu zamkniętym;

- zmniejszenie poziomu zanieczyszczeń w celu ochrony zdrowia obywateli oraz zminimalizowania degradacji środowiska;

- przeciwdziałanie utracie różnorodności biologicznej dla zachowania bogactwa otaczających nas ekosystemów gatunków i genów, które zapewniają m.in. zdrową żywność czy pitną wodę, a także decydują o dziedziczonych właściwościach organizmów;

- dążenie do produkcji żywności zrównoważonej, tj. żywności zdrowej, ekologicznej, lokalnej, świeżej i bezpiecznej, przy uwzględnieniu warunków społecznych i ekonomicznych.

Osiągnięcie tego celu będzie wymagało współdziałania społeczeństw na różnych poziomach kompetencji, od władz unijnych, rządowych, regionalnych i lokalnych poprzez wszystkie sektory gospodarki aż po szkolnictwo, tak by zapewnić prawidłowy i zharmonizowany proces edukacji od lat najmłodszych.

Świadomość braku alternatywy dla chorej pod każdym względem naszej planety powinna być wśród ogółu społeczeństwa powszechna, podjęte strategie powinny być wdrażane w życie, a przyjęte kryteria i zasady w tym względzie bezwzględnie egzekwowane.

\section{Najważniejsze inicjatywy programu EZł}

Z uwagi na kompleksowość i wieloaspektowość programu Europejski Zielony Ład wiele inicjatyw jest zgłaszanych przez poszczególnych członków UE. Niemniej spośród tych projektów można wymienić siedem. Są to inicjatywy równoważne, nawzajem się uzupełniające i ze sobą powiązane, a o powodzeniu programu EZŁ będzie decydowało to, czy wszystkie one będą skutecznie i równocześnie realizowane i wdrażane (Komisja Europejska, 2019).

1. Ambitne cele klimatyczne UE do roku 2050 - osiągnięcie neutralności emisyjnej na poziomie globalnym dla $\mathrm{CO}_{2}$ do roku 2050 oraz skompensowanie emisji wszystkich innych gazów cieplarnianych poprzez ich absorpcję m.in. w rolnictwie czy leśnictwie po roku 2050.

2. Czysta, przystępna cenowo i bezpieczna energia - włączenie w szerokim zakresie odnawialnych źródeł energii do systemu energetycznego oraz zapewnienie stabilnych i bezpiecznych dostaw energii, w tym m.in. słonecznej, wodnej, wiatrowej, geotermalnej, a także bioenergii z biomasy, biogazu czy biopłynów (Dyrektywa 2018/2001).

3. Czysta gospodarka o obiegu zamkniętym - znaczące ograniczenie zapotrzebowania na surowce pierwotne poprzez m.in. zwiększenie współczynnika odzysku i recyklingu w procesach technologicznych, zastępowanie energochłonnych materiałów nowymi o lepszych parametrach, modernizacja lub wymiana przestarzałych instalacji przemysłowych, automatyzacja i cyfryzacja procesów technologicznych, redukcja gazów cieplarnianych, wzrost efektywności.

4. Budownictwo energooszczędne, $w$ tym bezemisyjne - minimalizacja strat ciepła do otoczenia, alternatywne źródła ciepła, inteligentne systemy elektroenergetyczne.

5. Zerowy poziom emisji zanieczyszczeń na rzecz nietoksycznego środowiska - ograniczenie zanieczyszczeń powietrza, wody i gleby związanych z nadmiarem substancji szczególnie szkodliwych dla zdrowia ludzi i dla środowiska, jak mikrodrobiny plastiku, chemikalia; odbudowa bioróżnorodności biologicznej w rzekach, jeziorach czy w morzach; ograniczenie zanieczyszczeń z dużych instalacji przemysłowych; dostosowanie norm jakości powietrza do zaleceń Światowej Organizacji Zdrowia.

6. Sprawiedliwy, zdrowy i przyjazny środowisku system żywnościowy - produkowanie zrównoważonej żywności, zdrowej, bezpiecznej i bogatej w substancje odżywcze, wyeliminowanie środków chemicznych, w tym m.in. pestycydów czy antybiotyków, z działalności rolniczej, dbałość o utrzymanie różnorodności gatunków roślin i zwierząt w gospodarstwach rolnych, dążenie do podwyższania żyzności gleby, do spożywania żywności lokalnej, wyprodukowanej tradycyjnymi metodami upraw.

7. Zrównoważona i inteligentna mobilność - promowanie ekologicznych, niskoemisyjnych rodzajów transportu, ograniczenie negatywnego wpływu transportu na środowisko poprzez m.in. rozwój infrastruktury dla paliw alternatywnych, zintensyfikowanie działań na rzecz elektromobilności poprzez m.in. rozbudowę systemów ładowania pojazdów z napędem elektrycznym, rozwój zaawansowanego technologicznie przemysłu w tym zakresie (Ministerstwo Energii, 2017; Ministerstwo Infrastruktury, 2018).

\section{Transformacja sektora energetycznego}

Przed europejskim przemysłem, który ma ambicje być konkurencyjnym w skali globalnej, stoją dwie główne transformacje - ekologiczna i cyfrowa, których elementem wspólnym jest energetyka (Komisja Europejska, 2020). 
Pierwsza z nich ma zapewnić osiągnięcie neutralności klimatycznej, poprzez ograniczenie przez wszystkie sektory przemysłu ich śladu węglowego, a także zapewnić im wdrożenie rozwiązań w zakresie czystych technologii i nowych/ulepszonych modeli biznesowych. Warunkiem koniecznym efektywnej transformacji ekologicznej będzie zapewnienie dostaw czystej i przystępnej cenowo energii oraz surowców.

Druga transformacja ma na celu zwiększenie potencjału przemysłowego w zakresie krytycznej infrastruktury cyfrowej, co ułatwi rozwój przyszłych usług cyfrowych, zapewni rozwój w obszarze sztucznej inteligencji czy wielowymiarowej analizie metadanych przemysłowych przy wykorzystaniu nowoczesnej sieci 5G. Podjęte zostaną też działania nad opracowaniem infrastruktury dla komunikacji kwantowej, by zabezpieczyć cyfrowe zasoby państw członkowskich UE.

Podstawowe elementy transformacji przemysłowej to:

- egzekwowanie przepisów jednolitego rynku dla wzmocnienia wspólnych działań eliminujących bariery rozwoju; zapewnienie tzw. czterech swobód - przepływu osób, kapitału, towaru i usług;

- usuwanie barier podczas świadczenia usług transgranicznych, harmonizacja podatkowa, aktualizacja i rewizja prawodawstwa dotyczącego jednolitego rynku:

- sprawnie funkcjonujące systemy standaryzacji i certyfikacji,

- budowanie gospodarki za pośrednictwem m.in. platform internetowych, przy wykorzystaniu niestandardowych form zatrudnienia, jako bardziej dostępnych i elastycznych,

- wzmocnienie suwerenności technologicznej europejskich firm w skali globalnej; suwerenność ta jest warunkiem bezpieczeństwa, bo nadmierne uzależnienie od zagranicznych urządzeń/maszyn/usług/surowców/ oprogramowania stwarza duże ryzyko osłabienia UE czy blokady europejskich systemów,

- zaostrzenie/nasilenie/intensyfikacja kontroli celnych dla zapewnienia zgodności przewożonych produktów z unijnymi zasadami;

- wspieranie rozwoju kluczowych technologii wspomagających, mających strategiczne znaczenie dla przyszłości przemysłu UE, obejmujących m.in. technologie kwantowe, nanotechnologię, biotechnologię przemysłową czy mikroelektronikę.

Aby osiągnąć różnorodne, wyżej wymienione cele, należy mieć pełną świadomość, że - jak już wspomniano - kluczowym elementem transformacji ekologicznej i cyfrowej jest energetyka.

Strategia rozwoju tego sektora dąży do tego, aby zastąpić paliwa kopalne - dotychczasowe nośniki energii (gaz ziemny, ropa naftowa, węgiel) - nośnikami nowymi, minimalizującymi degradację środowiska naturalnego.
Takim wyzwaniem dla transformacji energetycznej skupiającej się na dekarbonizacji jest wodór. Można go otrzymywać $z$ różnych źródeł, niemniej nie każde z nich jest akceptowane z uwagi na pozostałości procesowe, mogące stanowić dodatkowe obciążenie energetyczne czy środowiskowe.

W zależności od źródła pochodzenia wodoru przyjmowane są w praktyce różne jego nazwy, m.in.:

- wodór zielony - wytwarzany za pomocą OZE;

- wodór niebieski - pochodzący z paliw kopalnych, lecz oczyszczony z $\mathrm{CO}_{2}$ z wykorzystaniem technologii wychwytywania i składowania $\mathrm{CO}_{2}$ (CCS), dopuszczony do stosowania przejściowo;

- wodór fioletowy - generowany z nadwyżek dostaw energii z elektrowni jądrowych;

- wodór czarny - z węgla, z użyciem technologii zgazowania tego paliwa.

Spośród tych różnych źródeł wytwarzania wodoru pełną akceptację UE posiada wodór zielony, który w procesie generowania pozostawia najmniejszy ślad węglowy.

Wodór, jako efektywny nośnik energii, można wykorzystać m.in.:

- do magazynowania energii elektrycznej, docelowo wyprodukowanej z odnawialnych źródeł, zwłaszcza z wiatru i słońca; do bilansowania systemu elektroenergetycznego; do usprawnienia przesyłu energii (Dorociak i Tomecki, 2019);

- w transporcie do napędu samochodów osobowych i ciężarowych oraz autobusów, floty morskiej i rzecznej, a także pociągów i samolotów (poprzez zastosowanie m.in. wodorowych ogniw paliwowych) (Ministerstwo Energii, 2017; Ministerstwo Infrastruktury, 2018);

- w ciepłownictwie, poprzez zwiększenie w okresie przejściowym udziału wodoru w mieszaninie z gazem ziemnym, do ogrzewania gospodarstw domowych czy przez zastosowanie wodorowych ogniw paliwowych $w$ instalacjach kogeneracyjnych, produkujących zarówno ciepło, jak i energię elektryczną (Komisja Europejska, 2018);

- w szeregu procesów przemysłowych (m.in. hutniczych czy chemicznych, w których produkcja wymaga wysokich temperatur, uzyskiwanych obecnie ze spalania paliw kopalnych. Aby dokonać tak całkowitego przeobrażenia sektorów energetyki poszczególnych krajów UE, niezbędne jest opracowanie i wdrożenie krajowych strategii wodorowych. Strategie te powinny uwzględniać z jednej strony okresy przejściowe sprzyjające transformacji energetycznej, w których paliwa kopalne z konieczności nadal będą odgrywać istotną rolę, z drugiej strony - realną wizję zapewnienia czystej i akceptowalnej cenowo energii.

Niezwykle ważnym elementem strategii jest określenie kosztów tej transformacji, a także zidentyfikowanie źródeł pozyskania funduszy na realizację długofalowych celów w energetyce. 
A zatem odejście od paliw kopalnych na rzecz wodoru produkowanego bezemisyjnie, będącego czystym źródłem energii, jest trendem globalnym, wynikającym z troski o środowisko i klimat oraz niepozostawiającym w chwili obecnej innego wyboru dla społeczeństw.

\section{Krajowa strategia wodorowa}

Strategia wodorowa, związana nie tylko z nowymi technologiami pozyskiwania wodoru, ale również uwzględniająca cały kompleks zagadnień dotyczących przesyłu i dystrybucji wodoru, jego magazynowania i użytkowania, spraw legislacyjnych czy normalizacyjnych, powinna wytyczać priorytetowe kierunki prac i zapewnić rozwój tzw. energetyki wodorowej.

Strategie wodorowe opracowywane są w poszczególnych krajach i znajdują się one na różnych etapach procedowania. Taką krajową strategię dla Polski przygotowuje Ministerstwo Klimatu. Jesienią 2020 r. zostanie ona skierowana do konsultacji społecznych, tak by przed końcem roku mogła być przyjęta przez rząd (Ministerstwo Aktywów Państwowych, 2019).

Obecnie podejmowany jest cały szereg działań w tym zakresie. Między innymi w dniu 7 lipca 2020 r. minister klimatu Michał Kurtyka podpisał z najważniejszymi spółkami sektora energetycznego i transportowego list intencyjny o ustanowieniu partnerstwa na rzecz budowy gospodarki wodorowej i zawarciu sektorowego porozumienia wodorowego. Wśród grona 25 firm sygnatariuszy ww. porozumienia, obok takich firm jak PGNiG S.A., PKN ORLEN S.A., Grupa LOTOS S.A. czy GazSystem S.A., jest Instytut Nafty i Gazu - Państwowy Instytut Badawczy. Celem tych działań jest współpraca przemysłu i instytutów badawczych na rzecz budowy gospodarki wodorowej.

Każda z ww. firm opracowała już własne programy rozwoju pod kątem nowego paliwa przyszłości i je realizuje, np.:

- $\quad$ PGNiG S.A. przyjęło do realizacji kompleksowy program pn. Czyste Paliwo dla Przyszłości, zawierający szereg projektów dotyczących wykorzystania wodoru w energetyce i transporcie, w tym m.in.:

- projekt Hydra Tank (budowa badawczej stacji tankowania pojazdów wodorem),

- projekt New Fuel Lab (utworzenie laboratorium do analizy czystości wodoru i badań nad paliwami alternatywnymi),

- projekt InGrid - Power to Gas (produkcja wodoru z wykorzystaniem OZE, badania możliwości przesyłu wodoru z wykorzystaniem sieci dystrybucji gazu ziemnego);

- $\quad$ PKN ORLEN S.A. prowadzi m.in. prace nad rozwojem paliw alternatywnych dla transportu, nad technologiami magazynowania, transportu i dystrybucji paliwa wodorowego, nad budową instalacji doczyszczania wodoru;
- Grupa LOTOS S.A. realizuje program Pure $\mathrm{H}_{2}$, obejmujący m.in. budowę instalacji oczyszczania wodoru, stacji sprzedaży i dystrybucji tego paliwa, a także rozwój technologii wykorzystania wodoru w transporcie samochodowym;

- Instytut Nafty i Gazu - Państwowy Instytut Badawczy od kilku lat prowadzi badania (Jaworski et al., 2019; Wojtowicz, 2019), obejmujące m.in.:

- oceny jakości paliw gazowych w aspekcie wprowadzenia wodoru do sieci gazowych,

- analizy wpływu dodatku wodoru do gazu ziemnego na pracę domowych i komercyjnych urządzeń gazowych,

- analizy wpływu dodatku wodoru do gazu ziemnego na bezpieczeństwo eksploatacji i dokładności wskazań gazomierzy miechowych czy na poszczególne elementy systemu gazowniczego,

- rozliczenia w jednostkach energii paliw gazowych wzbogaconych o wodór.

Prace badawcze w tym zakresie są kontynuowane przez Instytut i poszerzają one unikalną bazę danych do wykorzystania na rzecz przemysłu.

\section{Programy wspomagające transformację}

Program strategiczny Europejski Zielony Ład kładzie duży nacisk na opracowanie przez zespoły naukowo-badawcze w kooperacji z przemysłem innowacyjnych technologii wspomagających transformację. Zespoły te powinny się włączyć w realizację programów ramowych, takich jak np. Horyzont Europa czy Cyfrowa Europa. Programy te, podobnie jak m.in. fundusze strukturalne czy inwestycyjne UE, będą stanowić skoncentrowane źródło finansowania transformacji przemysłowej. A zatem od aktywności różnych środowisk - w tym jednostek naukowych i przemysłowych - w przygotowywaniu wniosków na projekty w ww. programach będzie zależała wysokość uzyskanych funduszy.

Przyszły ramowy program Horyzont Europa w zakresie badań naukowych i innowacji będzie obejmował pięć obszarów:

- zmiany klimatu;

- zdrowe oceany;

- miasta neutralne dla klimatu;

- zdrowa gleba i żywność;

- ochrona zdrowia.

W każdym z tych obszarów zagadnienia związane z nośnikami czystej energii będą bardzo ważne, jeśli nie najważniejsze. Program został zaplanowany na lata 2021-2027, na kwotę 100 mld $€$.

Z punktu widzenia rozwoju naszej gospodarki należy zwrócić uwagę na wykaz priorytetowych obszarów, w których Polska ma największą szansę na tworzenie innowacyjnych 
rozwiązań. Są to tzw. Krajowe Inteligentne Specjalizacje (KIS) (Ministerstwo Rozwoju, 2020), które uwzględniają m.in. zrównoważoną energetykę:

- KIS4 - Wysokosprawne, niskoemisyjne i zintegrowane układy wytwarzania, magazynowania, przesyłu i dystrybucji energii;

- KIS5 - Inteligentne i energooszczędne budownictwo;

- KIS6 - Rozwiązania transportowe przyjazne środowisku, a także gospodarkę o obiegu zamkniętym (KIS7) czy innowacyjne technologie i procesy przemysłowe.

Te priorytetowe działania wynikające z KIS powinny znaleźć swoje odzwierciedlenie w projektach wspierających transformację naszej gospodarki.

\section{Podsumowanie}

W chwili obecnej dopracowywane są i konsultowane programy strategiczne, których realizacja rozpocznie się w $2021 \mathrm{r}$. Zadecydują one o kształcie i zakresie transformacji naszej gospodarki, w tym przede wszystkim sektora energetyki.

Przemysł naftowy i gazowniczy mają w tej transformacji szczególną rolę do spełnienia, tak by dysponując doskonałą doświadczoną kadrą i odpowiednią infrastrukturą, można było podjąć wyzwanie zamiany nośnika energii, jakim są paliwa kopalne, na nowy, zeroemisyjny wodór.

Jest to program długofalowy, wymagający współpracy wielu sektorów, aby w ostateczności zmierzać do celu, jakim jest neutralna klimatycznie Europa.

\section{Literatura}

Dorociak M., Tomecki M., 2019. Wodorowa alternatywa. Raport 2019. Wyd. 300Gospodarka Sp. z o.o. https://static.300gospodarka.pl/media/2019/04/alternatywa_wodorowa_raport.pdf (dostęp: 06.2020).

Jaworski J., Kukulska-Zając, Kułaga P., 2019. Wybrane zagadnienia dotyczące wpływu dodatku wodoru do gazu ziemnego na elementy systemu gazowniczego. Nafta-Gaz, 10: 625-632. DOI: 10.18668/NG.2019.10.04.

Wojtowicz R., 2019. Analiza wpływu dodatku wodoru do gazu ziemnego na pracę urządzeń gazowych. Nafta-Gaz, 8: 465-473. DOI: 10.18668/NG.2019.08.03.

\section{Akty prawne i dokumenty normatywne}

Dyrektywa Parlamentu Europejskiego i Rady (UE) 2018/2001 z dnia 11 grudnia 2018 r. w sprawie promowania stosowania energii ze źródeł odnawialnych (Dz. Urz. UE L 328/82). < https://eur-lex.europa.eu/legal-content/PL/TXT/ $\mathrm{PDF} /$ ?uri=CELEX:32018L2001\&from=en> (dostęp: 06.2020).

Komisja Europejska, 2018. Komunikat Komisji do Parlamentu Europejskiego, Rady Europejskiej, Rady, Europejskiego Komitetu Ekonomiczno-Społecznego, Komitetu Regionów i Europejskiego Banku Inwestycyjnego. Czysta planeta dla wszystkich. Europejska długoterminowa wizja strategiczna dobrze prosperującej, nowoczesnej, konkurencyjnej i neutralnej dla klimatu gospodarki. Bruksela, 28.11.2018 r. COM(2018) 773 final. https://ec.europa. eu/transparency/regdoc/rep/1/2018/PL/COM-2018-773-F1-PLMAIN-PART-1.PDF (dostęp: 06.2020).

Komisja Europejska, 2019. Komunikat Komisji do Parlamentu Europejskiego, Rady Europejskiej, Europejskiego Komitetu Ekonomiczno-Społecznego i Komitetów Regionów. Europejski Zielony Ład. Bruksela, 11.12.2019. COM(2019) 640 final. $<$ https:// ec.europa.eu/transparency/regdoc/rep/1/2019/PL/COM-2019640-F1-PL-MAIN-PART-1.PDF> (dostęp: 06.2020).

Komisja Europejska, 2020. Komunikat Komisji do Parlamentu Europejskiego, Rady Europejskiej, Rady, Europejskiego Komitetu Ekonomiczno-Społecznego i Komitetu Regionów. Nowa strategia przemysłowa dla Europy. Bruksela, 10.03.2020. COM(2020) 102 final. <https://eur-lex.europa.eu/legal-content/PL/TXT/ PDF/?uri=CELEX:52020DC0102\&from=PL > (dostęp: 06.2020).

Ministerstwo Aktywów Państwowych, 2019. Krajowy plan na rzecz energii i klimatu na lata 2021-2030. Założenia i cele oraz polityki i działania. Wersja 4.1 z 18.12.2019. <https://www.gov.pl/attachment/c216508a-1805-4376-bedc-ebac09d1566e> (dostęp: 06.2020).

Ministerstwo Energii, 2017. Plan Rozwoju Elektromobilności w Polsce. Energia dla przyszłości. <https://www.gov.pl/attachment/75d21d4a-fd28-400e-b480-a3bbc3f7db5e > (dostęp: 06.2020).

Ministerstwo Infrastruktury, 2018. Zrównoważona mobilność w strategii zrównoważonego rozwoju transportu. Prezentacja Adriana Mazura. https://www.gov.pl/attachment/623cc4e1-2b8d-4e15b1f5-fc28db16d872 (dostęp: 06.2020).

Ministerstwo Rozwoju, 2020. Krajowe Inteligentne Specjalizacje. Wersja 6, obowiazuje od 1 stycznia 2020 r. <https://www.gov. pl/attachment/3659092b-977a-47a2-9e84-ea029a69f343> (dostęp.: 06.2020).

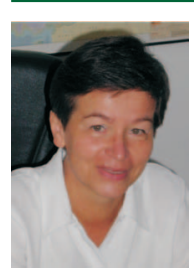

Dr hab. inż. Maria CIECHANOWSKA, prof. INiG - PIB

Dyrektor Instytutu Nafty i Gazu Państwowego Instytutu Badawczego ul. Lubicz 25 A

31-503 Kraków

E-mail: maria.ciechanowska@inig.pl 